\title{
Synthesis and Maturation of Phage P22 DNA
}

\section{Identification of Intermediates}

\author{
David Botstent $\dagger$ \\ Department of Human Genetics \\ University of Michigan, Ann Arbor, Michigan 48104, U.S.A.
}

(Received 6 November 196\%, and in revised form 26 March 1968)

\begin{abstract}
Two intermediates in the synthesis and maturation of phage P22 DNA have been identified by sedimentation of lysozyme-detergent lysates of induced lysogens or infected cells through sucrose density-gradients. Intermediate I contains most of the radioactivity incorporated during a short pulse of $\left[{ }^{3} \mathrm{H}\right]$ thymidine; it sediments at a rate in excess of $1000 \mathrm{~s}$. If a short pulse of $\left[{ }^{3} \mathrm{H}\right]$ thymidine is chased with unlabeled thymidine, labeled DNA appears in intermediate II, which has a sedimentation rate 1.2 to 1.7 times that of mature phage DNA in both neutral and alkaline sucrose gradients. ${ }^{32}$ P-labeled parental phage DNA appears first in intermediate I and later in intermediate II. The transfer of labeled DNA from intermediate I into intermediate II appears to be a late phage function; progeny phage heads contain DNA apparently derived from the intermediates.

It is suggested that intermediate I represents the replicating phage DNA specifically attached to some other constituent of the induced or infected cell, and that intermediate II contains polynucleotide chains longer than those of the mature phage DNA.
\end{abstract}

\section{Introduction}

Phage P22 is a temperate phage of Salmonella typhimurium. In addition to the capacity to lysogenize its host, and to act as the vector in generalized transduction, this phage has a property hitherto associated only with the T-even coliphages; it has a circular genetic map (Gough \& Levine, 1968). As in T4, the chromosome of phage P22 is a single linear double-stranded DNA molecule and is circularly permuted and terminally repetitious in its nucleotide sequence (Rhoades, MacHattie \& Thomas, manuscript in preparation).

These facts lend great interest to the processes of phage P22 DNA synthesis and maturation. The terminal redundancy and circular permutation of the information in the DNA must somehow be perpetuated. Streisinger and his collaborators (Streisinger, Edgar \& Denhardt, 1964 ; Sèchaud et al., 1965; Streisinger, Emrich \& Stahl, 1967) have suggested an ingenious explanation for the perpetuation of these features during the reproduction of T4 phage. Their scheme envisions the production, at some time during the synthesis and maturation of phage DNA, of DNA molecules longer than those extracted from phage heads. The complete phage genome would be repeated several times over in each of these long molecules. These would then be cut at random into the DNA molecules found in phage heads. The ends of different molecules would be at

$\dagger$ Present address: Department of Biology, Massachusetts Institute of Technology, Cambridge, Mass. 02139, U.S.A. 
different places in the genetic map, and each molecule would contain more than a complete set of phage genes.

This communication reports the beginning of a systematic attempt to describe and to understand the synthesis and maturation of phage P22 DNA. Evidence will be presented for the existence of intermediates in this process. One of these has many of the properties expected of phage DNA molecules having polynucleotide chains longer than those of DNA extracted from phage particles.

Similar investigations of the synthesis and maturation of T4 DNA have been reported by Frankel (1966a,b and $c)$; the basic approach and many of the techniques used here were adapted to the P22-Salmonella system from his work. Phage P22 is more amenable to study than phage $\mathrm{T} 4$ because of the lower molecular weight of its DNA. The estimated molecular weight of T-even phage DNA is about 120 to 130 million (Rubenstein, Thomas \& Hershey, 1961; Thomas, 1966), whereas the molecular weight of P22 DNA is about 27 million (Rhoades et al., manuscript in preparation; Studier, personal communication).

Some features of DNA synthesis are common to several bacteriophages. Foremost among these is the finding that the replicating form of the DNA is readily distinguishable from the DNA extracted from phage particles. This is true for T4 (Kozinski \& Lin, 1965; Frankel, 1966a) for T5 and T2 (Smith \& Burton, 1966) and for $\lambda$ (Smith \& Skalka, 1966) as well as for P22 (Botstein, 1967). In some cases, there is evidence of intracellular phage DNA which is longer than the mature phage DNA. $\dagger$

The only previous work on the synthesis of phage P22 DNA was done by Smith \& Levine (1965) under conditions of infection which led to the establishment of lysogeny. Although they found that some of the newly synthesized phage DNA had unusual sedimentation properties, they did not embark on a systematic analysis of phage DNA replication.

\section{Materials and Methods}

\section{(a) Chemicals}

Sarkosyl NL30 (sodium dodecyl sarcosinate, 30\% solution) was the gift of the Geigy Chemical Corporation. Angio-Conray (sodium iothalamate, $80 \%$ (w/v) solution) was purchased from the Mallinckrodt Chemical Works. EDTA was purchased as the disodium salt from Eastman Kodak. When dissolved in water at a concentration of $0.5 \mathrm{~m}$ and adjusted to $\mathrm{pH} 8.5$ with $\mathrm{NaOH}$ there is a faint yellow color, which is removed by passing the solution through a Millipore filter (average pore size, $0.45 \mu$ ). Pronase (B grade) was purchased from the California Biochemical Corporation. Lysozyme (muramidase, twice crystallized) was purchased from the Worthington Biochemical Corporation. Cesium chloride (99.95\%, optical grade) was the product of the Varlacoid Chemical Co. Reagent grade sucrose was purchased from Merck \& Co. [Methyl $\left.{ }^{3} \mathrm{H}\right]$ thymidine was purchased from the New England Nuclear Corporation. Carrier-free [ $\left.{ }^{32} \mathrm{P}\right]$ orthophosphate was obtained from Tracerlab, Inc. Dimethyl POPOP and PPO scintillators were purchased from the Packard Instrument Co. Casein hydrolysate was purchased from the Nutritional Biochemicals Corporation; it is a salt- and vitamin-free acid hydrolysate of dialysed casein in sterile $10 \%$ solution. It contains virtually no phosphate. All other chemicals were standard products of reagent grade.

\section{(b) Media}

The standard medium used is a Tris-glucose-Casamino acid medium in which the concentration of phosphorus (as phosphate) can be controlled. $200 \mathrm{ml}$. of this medium contains $20 \mathrm{ml}$. of $1 \mathrm{~m}$-Tris (pH 7.4); $4 \mathrm{ml} .10 \%$ casein hydrolysate; $1 \mathrm{ml} .40 \%$ (w/v) glucose; $1 \mathrm{mI}$.

$\dagger$ Mature phage DNA refers to any DNA having the properties of the DNA extracted from phage particles. 
$20 \%(\mathrm{w} / \mathrm{v}) \mathrm{NH}_{4} \mathrm{Cl} ; 0.5 \mathrm{ml} .1 \mathrm{M}-\mathrm{MgSO}_{4} ; 0.4 \mathrm{ml} .25 \%(\mathrm{w} / \mathrm{v}) \mathrm{NaCl}$. When phosphate is added to a final concentration of $20 \mu \mathrm{g}$ phosphorus/ml., the medium is called LCG20. When lower phosphorus concentrations are desired (for ${ }^{32} \mathrm{P}$-labeling), an appropriate amount of phosphate is added and the medium called LP/ $x$ where $x$ is the concentration of phosphorus in $\mu \mathrm{g} / \mathrm{ml}$.

Buffered saline is $0.85 \%(\mathrm{w} / \mathrm{v}) \mathrm{NaCl}$ and $0.066 \mathrm{~m}$-phosphate buffer $(\mathrm{pH} 7 \cdot 1)$. Trisbuffered saline contains $0.1 \mathrm{M}-$ Tris $(\mathrm{pH} 7 \cdot 2)$ in place of phosphate.

\section{(c) Bacteria and phage}

The strain of $S$. typhimurium used as host for P22 phage is strain 18 (Levine collection). It is a derivative of strain LT2 cured by Zinder (1958) of the PB1 phage. It was called strain SAl by Zinder.

The wild type $\left(c^{+}\right)$and the clear mutant $\left(c_{1}\right)$ were described by Levine (1957) and by Levine \& Curtiss (1961). The temperature-sensitive clear mutant $t s c_{2}$ phage (Levine \& Smith, 1964) produces a turbid plaque at $25^{\circ} \mathrm{C}$ and a clear one at $37^{\circ} \mathrm{C}$. Stable lysogens of this mutant phage can be made and maintained at $25^{\circ} \mathrm{C}$, but if such a lysogen is heated to $39^{\circ} \mathrm{C}$, it will be induced to produce progeny phage.

A temperature-inducible lysogen was made by infection of strain 18 with $t 8 c_{2}$ phage at $25^{\circ} \mathrm{C}$. It grows normally at $25^{\circ} \mathrm{C}$, but upon shift of temperature to $39^{\circ} \mathrm{C}$ more than $98 \%$ of the cells become infective centers.

The procedures used for the growth, maintenance and assay of P22 phage are described by Levine (1957).

\section{(d) Purification of phage stocks in cesium chloride}

Spontaneous phage lysates are concentrated by centrifugation (in a Sorvall SS34 rotor) at $17,000 \mathrm{rev} . / \mathrm{min}$ for $90 \mathrm{~min}$. The phage pellet is resuspended in buffered saline and applied to a stepwise gradient of $\mathrm{CsCl}$. After centrifugation at $45,000 \mathrm{rev} . / \mathrm{min}$ in a Spinco SW50L rotor for $20 \mathrm{~min}$, the phage band is visible and is collected through a hole in the bottom of the tube. $\mathrm{CsCl}$ is removed by dialysis overnight against 1000 vol. of buffered

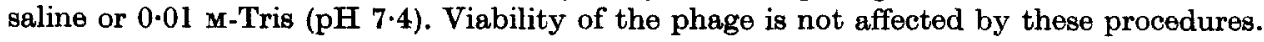

\section{(e) Preparation of ${ }^{32} P$-labeled phage}

A culture of strain 18 grown overnight at $37^{\circ} \mathrm{C}$ without aeration in LCG20 medium, washed by centrifugation, and resuspended in Tris-buffered saline is used to inoculate LP $/ 0.5$ medium to a density of about $10^{7} \mathrm{cells} / \mathrm{ml}$. This suspension is shaken at $37^{\circ} \mathrm{C}$ until the cell density reaches $10^{8}$ cells $/ \mathrm{ml}$., at which time phage are added to a final multiplicity of 5 phage/cell. Simultaneously, carrier-free ${ }^{32} \mathrm{PO}_{4}$ is added to a maximum concentration of $10 \mu \mathrm{c} / \mathrm{ml}$. After lysis of the culture, phage are collected and purified as described above. The operations, beginning with the addition of ${ }^{32} \mathrm{P}$ and ending with the collection of the $\mathrm{CsCl}$ gradient, take about $2.5 \mathrm{hr} .20 \mathrm{ml}$. of culture yields about $5 \times 10^{11}$ plaque-forming units each containing about $10^{-5} \mathrm{cts} / \mathrm{min}$.

\section{(f) Preparation of ${ }^{3} \mathrm{H}$-labeled phage}

Strain 18 bacteria growing exponentially in LCG20 at $37^{\circ} \mathrm{C}$ are infected with $5 c_{1}$ phage per bacterium. Simultaneously, $250 \mu \mathrm{g}$ deoxyadenosine $/ \mathrm{ml}$. and $10 \mu \mathrm{C}\left[{ }^{3} \mathrm{H}\right]$ thymidine/ml. are added. After lysis of the culturo, phago are isolated and purified as described above.

\section{(g) Preparation of purified ${ }^{23} \mathrm{P}$ - or ${ }^{3} \mathrm{H}$-labeled phage $\mathrm{DNA}$}

Radioactive phage purified in $\mathrm{CsCl}$ are shaken gently (in the cold) with an equal vol. of water-saturated redistilled phenol. The aqueous layer is removed and the phenol layer extracted again with $0.5 \mathrm{vol}$. of Tris-buffered saline. The aqueous layer is again removed and mixed with the aqueous layer from the first extraction. The mixture is extracted once more with an equal vol. of phenol, and the aqueous layer, which usually contains about $95 \%$ of the input radioactive material, is dialyzed for $36 \mathrm{hr}$ against 3 changes of $1000 \mathrm{vol}$. of $0.01 \mathrm{M}$-Tris, $0.01 \mathrm{M}$-EDTA ( $\mathrm{pH} 8$ ). A portion of this preparation is added to enough $\mathrm{CaCl}(65 \% \mathrm{w} / \mathrm{w})$ to produce a final density of $1.7 \mathrm{~g} / \mathrm{cc}$. This is centrifuged in a Spinco $\mathrm{SW} 39$ rotor at $35,000 \mathrm{rev} . / \mathrm{min}$ for $36 \mathrm{hr}$. The DNA band is collected and dialyzed against 
$1000 \mathrm{vol}$. of $0.01 \mathrm{~m}$-Tris ( $\mathrm{pH} 8$ ) for $24 \mathrm{hr}$. The sedimentation rate of DNA isolated in this way is indistinguishable from the DNA of phage lysed by heating to $65^{\circ} \mathrm{C}$ for $20 \mathrm{~min}$ in $2 \%$ Sarkosyl detergent.

\section{(h) Temperature induction and infection}

Induction of the temperature-sensitive lysogen was accomplished by centrifuging the cells $\left(10^{8}\right.$ cells $/ \mathrm{ml}$.), growing exponentially in LCG20 at $25^{\circ} \mathrm{C}$, at low speed at room temperature, resuspending the pellet in 0.1 vol. of LCG20 and diluting 10 -fold into warmed $\left(39^{\circ} \mathrm{C}\right)$ LCG20.

Infection was accomplished by adding an equal vol. of strain 18 cells $\left(2 \times 10^{8} / \mathrm{ml}\right.$.) growing exponentially in LCG20 at $37^{\circ} \mathrm{C}$ into warm LCG20 containing the appropriate number of phage (usually $4 \times 10^{9} \mathrm{phage} / \mathrm{ml}$.). All these operations were done in side-arm flasks; cell density and growth were followed in a Klett colorimeter.

Spontaneous lysis occurs at about $35 \mathrm{~min}$ after infection with phage $c_{1}$ and about $55 \mathrm{~min}$ after shifting strain $18\left(t s c_{2}\right)$ cells to $39^{\circ} \mathrm{C}$.

\section{(i) Pulse-labeling of intracellular DNA}

$\left[{ }^{3} \mathrm{H}\right]$ Thymidine was added at the appropriate time to a final concentration of $20 \mu \mathrm{C} / \mathrm{ml}$.; the specific activity varied between 10 and $17 \mathrm{c} / \mathrm{m}$-mole. Growth was stopped by removing a sample $(1 \mathrm{ml}$.) and vigorously squirting it into an equal vol. of the lysis mixture (see below) with a spring-loaded syringe; no further incorporation of $\left[{ }^{3} \mathrm{H}\right]$ thymidine can be detected after mixing with the lysis mixture. If a chase was desired, non-radioactive thymidine was added after $2 \mathrm{~min}$ to a final concentration of 1.5 to $2 \mathrm{mg} / \mathrm{ml}$. During such a chase, incorporation of radioactivity continues at a decreasing rate for about 3 to $5 \mathrm{~min}$.

\section{(j) Lysis procedure}

The procedure is a modification of that described by Frankel (1966b). $10 \mathrm{ml}$. of the lysis mixture contains $1 \mathrm{ml} .1 \mathrm{M} \cdot$ Tris ( $\mathrm{pH} \mathrm{8.0);2} \mathrm{ml.} \mathrm{0.5} \mathrm{M-EDTA} \mathrm{(pH} \mathrm{8.5)} \mathrm{(filtered);} 0.1 \mathrm{ml}$. $1 \mathrm{M}-\mathrm{NaCN}$; and 0.1 to $0.2 \mathrm{ml}$. lysozyme $(10 \mathrm{mg} / \mathrm{ml}$.) freshly prepared in $0.25 \mathrm{M}$-Tris (pH 8.0). After mixing equal vol. of culture and lysis mixture, the lysates are handled extremely gently. Subsequent reagents are added down the side of the tube, and mixing is by diffusion and convection only. The mixture is incubated for $10 \mathrm{~min}$ at $37^{\circ} \mathrm{C}$. It is then transferred carefully to $65^{\circ} \mathrm{C}$. After $3 \mathrm{~min}$, enough Sarkosyl is added (down the side of the tube) to give a final concentration of $2 \%$, and incubation is continued at $65^{\circ} \mathrm{C}$ for 20 more min. The lysates are stored thereafter at room temperature. The neutral sucrose gradient profiles of these lysates remain the same for at least 6 weeks.

If the cell concentration in the solution to be lysed exceeds $3 \times 10^{8} / \mathrm{ml}$., the resulting sucrose density-gradient profiles are variable, presumably because of DNA aggregation effects. The method described above lyses phage particles as well as bacteria.

\section{(k) Zone sedimentation through sucrose density-gradients}

\section{(i) Neutral gradients}

Neutral sucrose solutions are made up containing either 5 or $20 \%$ sucrose and 0.02 M-Tris, 0.01 m-EDTA and 0.1\% Sarkosyl. The final pH is 8. The Sarkosyl is included to give an even drop-size; if the detergent is not included, the drops get very small at the top of the gradient. With $0.1 \%$ detergent, the drop-size and number of drops per gradient are constant and reproducible.

Before making the gradients, $0.3 \mathrm{ml}$. of a solution of high density consisting of $80 \%$ $(w / v)$ iothalamic acid (Angio-Conray) and $20 \%(w / v)$ sucrose is pipetted into the bottom of the 5-ml. cellulose nitrate tubes. The gradients are then made on top of this material (Britten \& Roberts, 1960) using a Buchler gradient mixer which makes 3 linear gradients simultaneously. The final volume of the whole system is $4.9 \mathrm{ml}$. The material at the bottom facilitates the recovery of material which would otherwise become a pellet. I am indebted to Dr S. Altman (Altman \& Lerman, manuscript in preparation) for suggesting this technique.

Samples of lysate $(0 \cdot 1 \mathrm{ml}$.) are layered on top of the gradients using polyethylene tubing (Clay-Adams, no. PE 240) driven by the screw adjustment on a 1-ml. automatic syringe. 
(ii) Alkaline gradients

Alkaline sucrose solutions contain either 5\% or $20 \%$ sucrose, 0.005 M-EDTA and $0.1 \%$ Sarkosyl. The solutions are titrated with a $\mathrm{pH}$ meter (calibrated at $\mathrm{pH} 10$ ) to $\mathrm{pH} 12.1$ with $10 \mathrm{M} \cdot \mathrm{NaOH}$ before being made up to final volume. $4 \cdot 6 \cdot \mathrm{ml}$. gradients are made on top of $0.1 \mathrm{ml}$. of the iothalumate-sucrose solution. Then $0.1 \mathrm{ml}$. of a solution $0.35 \mathrm{~m}$ in $\mathrm{NaOH}$ and containing $0.1 \%(\mathrm{w} / \mathrm{v})$ Sarkosyl is layered on the gradient, followed by application of $0.1 \mathrm{ml}$. of lysate. The two layers can be seen to mix. This expedient serves to bring the lysato to alkaline $\mathrm{pH}$ without additional handling.

Strand separation does occur in these alkaline gradients. Purified P22 DNA isolated from such a gradient and resedimented in neutral sucrose sediments as a single band in the region expected for "neutral denatured" DNA. Studier (1965) presents evidence that the transition from native to neutral denatured DNA requires strand separation.

Neutral and alkaline gradients are allowed to stand for 15 to $30 \mathrm{~min}$ before centrifugation to permit the very viscous lysates to form an even layer on top of the gradients. The speeds and times of the centrifugations are indicated in the legends to the Tables and Figures, as are the recoveries from each gradient.

Gradients are collected by puncturing the bottom of the tube with a needle; the drops are collected onto numbered reotangles of Whatman $3 \mathrm{MM}$ filter paper ( $\frac{9}{18}$ in. by $1 \frac{5}{8}$ in.). These are thoroughly dried and soaked twice in cold $10 \%$ trichloroacetic acid for $30 \mathrm{~min}$; washed in $5 \%$ trichloroacetic acid for $15 \mathrm{~min}$, and finally in cold acetone for $15 \mathrm{~min}$. After being dried in air, they are placed in vials containing $15 \mathrm{ml}$. of mixture of $300 \mathrm{mg}$ dimethyl POPOP and $5 \mathrm{~g} \mathrm{PPO/l}$. of toluene and counted in a Packard 3-channel scintillation counter.

\section{(1) DNA-DNA hybridization}

Unlabeled DNA purified from phage particles or from bacteria was denatured and attached to nitrocellulose membrane filters as described by Denhardt (1966). The binding of radioactive denatured DNA to these filters measures hybridization with attached DNA.

Radioactive lysates to be hybridized were dialyzed for $72 \mathrm{hr}$ against 4 changes of $1000 \mathrm{vol}$. of $0.01 \mathrm{M}$-Tris and 0.01 M-EDTA (pH 8.0) at room temperature to remove all soluble radioactive material and detergent. Samples were diluted and the DNA denatured in boiling water for $10 \mathrm{~min}$. The annealing mixtures contained 0.08 to $0.12 \mu \mathrm{g}$ of radioactive DNA, Denhardt's (1966) polymer mixture, and one of 3 kinds of filters: "phage" filters had been exposed to $11.2 \mu \mathrm{g}$ of denatured purified phage DNA; "bacterial" filters to $11.0 \mu \mathrm{g}$ of denatured purified bacterial DNA; and the "blank" filters to no DNA. All filters had been pre-incubated in the polymer mixture. Annealing was carried out in a total volume of $1 \mathrm{ml}$. for 12 to $16 \mathrm{hr}$ at $65^{\circ} \mathrm{C}$. The binding activity to blank filters varied from 3 to $16 \%$ of the total acid-precipitable radioactive material applied, and the total recovery on filters varied from 25 to $75 \%$ of that applied. These variations were much smaller among samples run at the same time, and the only values accepted were those where duplicates were within $10 \%$ in all parameters. Although variation in recovery was very large between determinations 'on a given sample on two different days, the ratio of phagebinding to bacterial-binding activity remained quite constant. For example, one sample gave only $26 \%$ recovery in one experiment, with a phage/bacterial ratio of $2 \cdot 6$. In a second experiment the same sample gave a recovery of $46 \%$, and the ratio was $2 \cdot 8$. The reasons for these variations are not clear.

\section{Results}

\section{(a) Incorporation of $\left[{ }^{3} \mathrm{H}\right]$ thymidine into $\mathrm{DNA}$ during lytic cycles of phage growth}

Incorporation was studied after induction of a temperature-inducible lysogen (Fig. 1(a)) and after infection with a non-lysogenizing $\left(c_{1}\right)$ phage strain (Fig. 1(b)). In both cases the rate of DNA synthesis shows an initial drop, rises suddenly about ten minutes later, and continues at a high rate until shortly before lysis. It will be shown below that the rise at ten minutes is due primarily to the synthesis of phage DNA. 

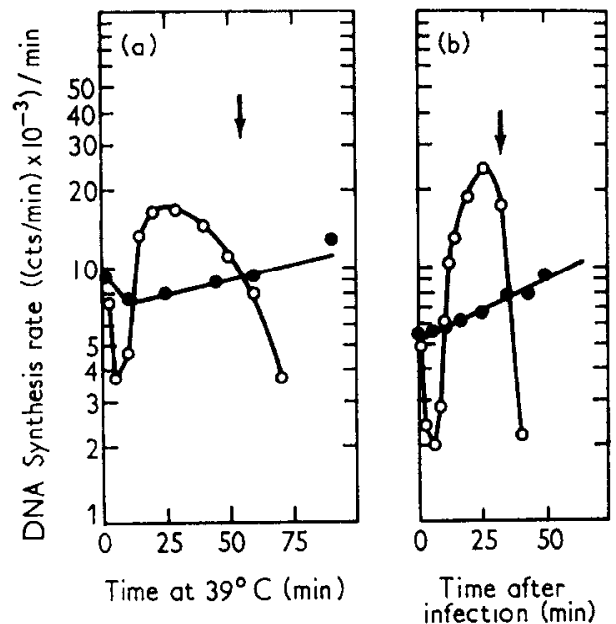

Fia. 1. Incorporation of $\left[{ }^{3} \mathrm{H}\right]$ thymidine during lytic cycles of phage growth.

The procedure is described by Smith \& Levine (1964). Growth was followed in a Klett colorimeter; the arrows indicate the onset of lysis.

(a) Temperature induction: The temperature-inducible lysogen, strain $18\left(t s \mathrm{C}_{2}\right)(-\mathrm{O}-\mathrm{O}-)$ and the non-lysogenic parent, strain 18 (- - - ) growing exponentially at $25^{\circ} \mathrm{C}$ were harvested and diluted into medium at $39^{\circ} \mathrm{C}$.

(b) Infeetion with $c_{1}$ phage: strain 18 cells growing exponentially at $37^{\circ} \mathrm{C}$ were infected with

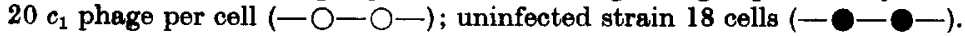

\section{TABLE 1}

Distribution in sucrose density-gradients of radioactivity incorporated during 1-min pulses of $\left[{ }^{3} H\right]$ thymidine administered after induction of a temperatureinducible lysogen

\begin{tabular}{cccc}
\hline $\begin{array}{c}\text { Beginning of } \\
\text { pulse (min } \\
\text { after induction) }\end{array}$ & $\begin{array}{c}\text { Radioactivity } \\
\text { incorporated } \\
(\text { cts } / \text { min/ } \\
0.1 \text { ml. })\end{array}$ & $\begin{array}{c}\text { Total radio- } \\
\text { activity } \\
\text { recovered } \\
(\%)\end{array}$ & $\begin{array}{c}\text { Proportion } \\
\text { recovered at } \\
\text { the bottom } \\
(\%) \dagger\end{array}$ \\
\hline 10 & 462 & 88 & 61 \\
15 & 873 & 93 & 63 \\
20 & 1392 & 84 & 56 \\
30 & 1635 & 91 & 62 \\
40 & 1408 & 89 & 60 \\
50 & 1252 & 96 & 48 \\
\hline
\end{tabular}

Bacteria growing exponentially at $25^{\circ} \mathrm{C}$ were harvested and diluted into medium at $39^{\circ} \mathrm{C}$. The temperature-inducible lysogen was strain $18\left(t s c_{2}\right)$ and the non-lysogen control was strain 18. Pulses were begun by adding $1 \mathrm{ml}$. of culture to $10 \mu \mathrm{C}$ of $\left[{ }^{3} \mathrm{H}\right]$ thymidine $(17 \mathrm{c} / \mathrm{m}$-mole $)$ and terminated 1 min later by adding an equal vol. of lysis mixture. The lysis procedure and the preparation of sucrose gradients having dense material at the bottom to ensure recovery are described in the Materials and Methods. $0.1 \mathrm{ml}$. of lysate was applied to each gradient; the gradients were centrifuged for $30 \mathrm{~min}$ at $25,000 \mathrm{rev} . / \mathrm{min}$ in a Spinco $\mathrm{SW39}$ rotor at $23^{\circ} \mathrm{C}$. Gradient collection and determination of acid-insoluble radioactive material were carried out as described in the Materials and Methods. The number of fractions obtained per gradient varied from 32 to 36.

$\dagger$ Proportion recovered at the bottom is radioactive material recovered in the first six frantions of the gradient divided by the total radioactive material recovered in the gradient expressed as a percentage. 
(b) Sedimentation behavior of DNA pulse-labeled after temperature induction

The DNA labeled in 1-minute pulses of $\left[{ }^{3} \mathrm{H}\right]$ thymidine administered at intervals throughout the latent period was examined in neutral sucrose gradients (Table 1). About $60 \%$ of the DNA labeled any time after the onset of phage DNA synthesis is recovered at the bottom of the gradient. This material is not bacterial DNA, as shown by the analysis of DNA extracted from uniformly labeled non-lysogenic cells (Fig. 2).

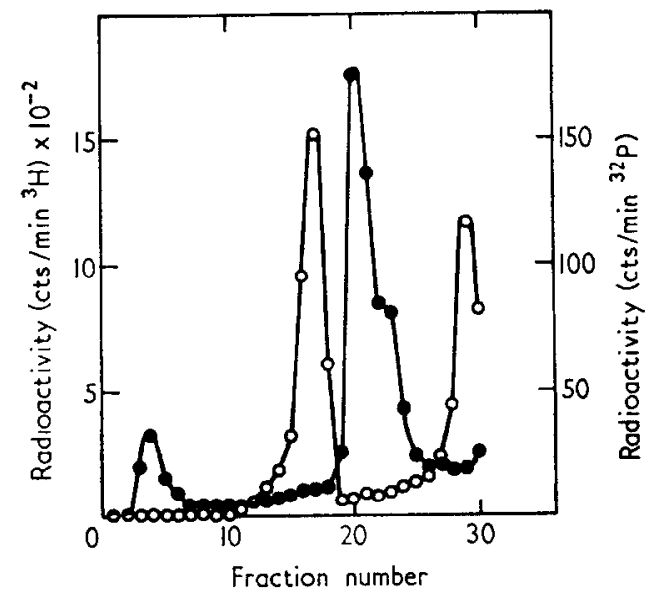

Fra. 2. Sedimentation rate of uniformly labeled bacterial DNA.

Strain 18 cells were grown at $37^{\circ} \mathrm{C}$ from a density of $6 \times 10^{6}$ cells $/ \mathrm{ml}$. to $10^{8} \mathrm{cells} / \mathrm{ml}$. in LCG20 medium containing $250 \mu \mathrm{g}$ deoxyadenosine $/ \mathrm{ml}$. and $5 \mu \mathrm{c}\left(10 \mathrm{c} / \mathrm{m}\right.$-mole) $\left[{ }^{3} \mathrm{H}\right]$ thymidine $/ \mathrm{ml}$. Uptake of radioactivity was proportional to growth over tho last four generations. Lysis was carriod out as described in Materials and Methods; a small number of ${ }^{32}$ P-labeled phage were lysed simultaneously to provide a marker for the phage DNA position. The lysate was layered on a neutral sucrose gradient of the usual composition together with whole, unlysed, ${ }^{32}$ P-labeled phage. Thus the gradient contains two ${ }^{32} \mathrm{P}$-labeled species; phage DNA and whole phage particles. The conditions of centrifugation and analysis of the gradient are the same as those in the legend to Table 1. $\left(-\mathrm{O}-\mathrm{O}^{3} \mathrm{H}\right.$ radioactivity; $(-\mathrm{O}-\mathrm{O}-)^{32} \mathrm{P}$ radioactivity. Sedimentation is from right to left in this and subsoquont Figuros.

Here most of the bacterial DNA sedimented through about one-third the length of the gradient; the intact phage particle marker sedimented through about half the length; and a phage DNA marker hardly sedimented at all. The fact that most of the bacterial DNA does not sediment to the bottom of the gradient makes it unlikely that the high sedimentation coefficient of pulse-labeled phage DNA is the result of tangling with bacterial DNA. Furthermore, in the gradients which provided the data in Table 1 there usually is a component sedimenting at the same rate as bacterial DNA; however, this material accounts for $15 \%$ or less of the total pulse-labeled DNA after induction.

The proportion of radioactivity at the bottom of the gradients from the induction experiment (Table 1) is probably an underestimate. First, this material is the only defined component in the gradients other than a small amount of DNA, presumably bacterial, at $250 \mathrm{~s}$; the remainder of the acid-precipitable radioactive material is spread evenly throughout the gradients. Second, resedimentation of isolated bottom component reproduces the pattern: $70 \%$ of the material again at the bottom, and the rest distributed throughout the gradient. Therefore the data in Table I are interpreted as indicating that most, if not all, of the $\left[{ }^{3} \mathrm{H}\right]$ thymidine incorporated in one minute is 
incorporated into the very rapidly sedimenting species at the bottom of the gradients.

If one assumes a sedimentation coefficient of about $380 \mathrm{~s}$ for the phage particles (unpublished results) and $33 \mathrm{~s}$ for the phage DNA (Studier, personal communication), the bacterial DNA (Fig. 2) has a sedimentation coefficient of about $250 \mathrm{~s}$ and the bottom of the gradient will represent a minimum sedimentation rate of $800 \mathrm{~s}$. Other experiments of this kind have shown that the DNA pulse-labeled after induction of strain $18\left(t s c_{2}\right)$ has a sedimentation rate of at least $1000 \mathrm{~s}$.

\section{(c) The fate of DNA pulse-labeled after temperature induction}

A two-minute pulse of $\left[{ }^{3} \mathrm{H}\right]$ thymidine was administered after the onset of phage DNA synthesis (20 minutes after induction) and chased with excess unlabeled thymidine. Samples were taken at intervals thereafter. The lysis mixture contained a trace amount of ${ }^{32} \mathrm{P}$-labeled phage. Since the procedure lyses the phage, this provides ${ }^{32} \mathrm{P}$-labeled phage DNA as a marker in the sucrose gradients. A control experiment showed that this DNA is indistinguishable in sedimentation from ${ }^{3} \mathrm{H}$-labeled DNA extracted from phage particles with phenol and purified in $\mathrm{CsCl}$ equilibrium densitygradients. Addition of the phage before lysis also provides a control for simple aggregation artifacts which might otherwise be invoked to explain some of the results.
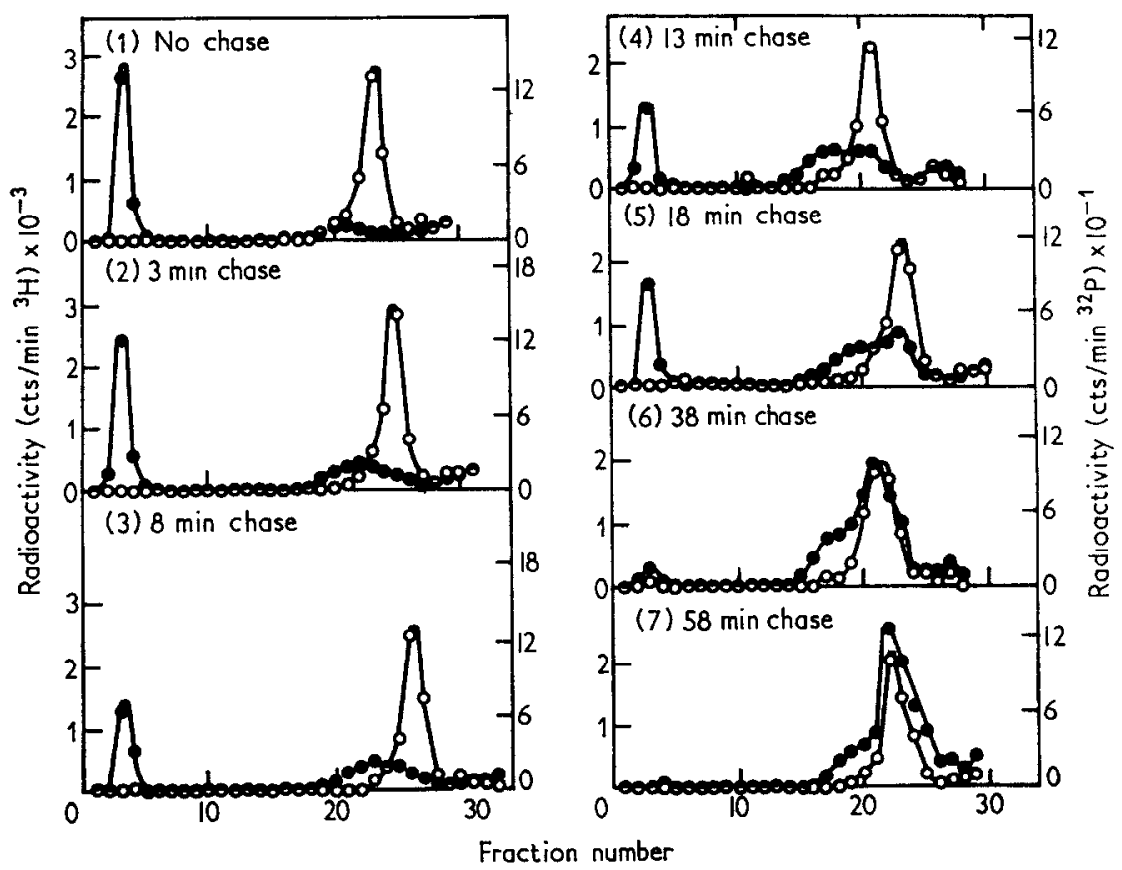

Frg. 3. The fate of pulse-labeled phage DNA after temperature induction : neutral sucrose gradients.

Strain $18\left(t s c_{2}\right)$ cells were induced by dilution into medium at $40^{\circ} \mathrm{C}$ to start experiment. [ $\left.{ }^{3} \mathrm{H}\right]$ Thymidine ( $20 \mu \mathrm{c} / \mathrm{ml}$.; $10 \mathrm{c} / \mathrm{m}-\mathrm{mole})$ was added $20 \mathrm{~min}$ after induction; the pulse was terminated $2 \mathrm{~min}$ later by the addition of $2 \mathrm{mg}$ of unlabeled thymidine/ml. The lysis mixture contained a small number of ${ }^{32} \mathrm{P}$-labeled phage to serve as a marker. The gredients had a cushion of dense material at the bottom to insure recovery. Sedimentation was for $60 \mathrm{~min}$ at $35,000 \mathrm{rev} . / \mathrm{min}$ at $23^{\circ} \mathrm{C}$. Recovery of ${ }^{32} \mathrm{P}$ radioactivity in the gradient was always better than $90 \%$; of ${ }^{3} \mathrm{H}$ radioactivity always better than $82 \%$. (-O-O-) ${ }^{32} \mathrm{P}$ radioactivity; ( $\left.-\mathrm{O}-\mathrm{O}-\right)^{3} \mathrm{H}$ radioactivity. 


\section{(i) Sedimentation through neutral sucrose gradients}

Profiles from neutral sucrose gradients of these lysates are shown in Figure 3. In order to resolve the peaks near the top of the gradients, these gradients were run at higher speeds and longer times than the previous ones (Table 1 and Fig. 2). Unfortunately, bacterial DNA (about $250 \mathrm{~s}$ ) now sediments to the bottom of the gradients. Nevertheless, control experiments showed that there was a negligible amount of $250 \mathrm{~s}$ material in the lysates of this and all subsequent experiments. Furthermore, hybridization experiments (see below) indicate that the pulse-labeled DNA has little affinity for purified bacterial DNA.

Immediately after the pulse, most of the labeled DNA is found at the bottom of the gradient (Fig. 3, frame 1). None of the ${ }^{32}$ P-labeled phage DNA marker is found at this position in any of the gradients in Figure 3, and there is no pulse-labeled DNA at the marker position. As discussed previously (Table 1) the pulse-label is at the bottom no matter when the pulse is administered.

As DNA synthesis continues in the presence of unlabeled thymidine, pulse-labeled DNA begins to appear in a position in the gradient corresponding to a sedimentation rate $1 \cdot 3$ to $1 \cdot 7$ times the sedimentation rate of the mature phage DNA (frames 2 and 3 ).

Near the end of the latent period (frames 4 and 5), some of the pulse-labeled phage DNA appears at the marker position. By the time the culture lyses spontaneously

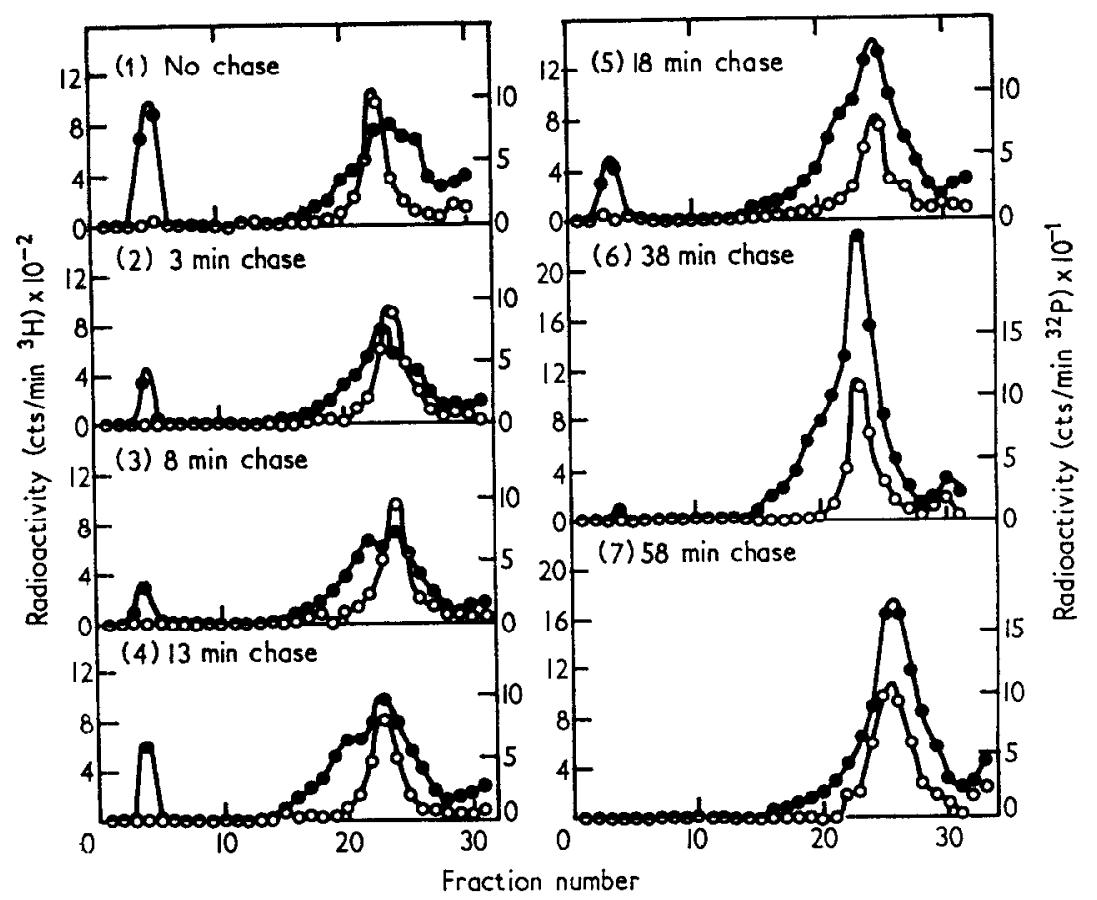

Fra. 4. The fate of pulse-labeled phage DNA after temperature induction: alkaline sucrose gradients.

The origin of the lysates is described in the legend to Fig. 3. The preparation of the alkaline gradients and the adjustment of the $\mathrm{pH}$ of the lysates are described in the Materials and Methods section. Sodimontation was for $90 \mathrm{~min}$ at $35,000 \mathrm{rev} . / \mathrm{min}$ at $23^{\circ} \mathrm{C}$. Reoovery of ${ }^{32} \mathrm{P}$ radioactivity was always better than $88 \%$; of ${ }^{3} \mathrm{H}$ radioactivity always better than $77 \%$. (-O-O-) ${ }^{32} \mathrm{P}$ radioactivity; (-O-O-) ${ }^{3} \mathrm{H}$ radioactivity. 
(between frames 6 and 7), almost all of the pulse-labeled DNA has a sedimentation rate similar to that of the marker DNA extracted from phage particles.

To summarize, DNA pulse-labeled after induction has been observed in two forms which sediment more rapidly than DNA extracted from phage particles. These forms are apparently derived from intermediates in the synthesis and maturation of phage DNA, since $\left[{ }^{3} \mathrm{H}\right]$ thymidine appears in them before it appears as mature phage DNA. In order to simplify the subsequent presentation, the sedimentation forms are defined as follows.

Intermediate $I$. This material sediments at a rate exceeding $1000 \mathrm{~s}$. It contains most of the pulse-label incorporated in short pulses administered at any time after the onset of phage DNA synthesis, provided that the cells are lysed immediately. It thus appears to be the replicating form as seen in the present procedure.

Intermediate $I I$. This material sediments somewhat more rapidly than DNA extracted from phage particles. It is observed only if DNA synthesis is allowed to continue after pulse-labeling.

Mature phage DNA. DNA having a sedimentation rate indistinguishable from that of DNA extracted from phage particles.

It must be stressed that these materials as defined have been subjected to all the manipulations of the lysis procedure, and that they may well be different in the intact cells.

\section{(ii) Sedimentation through alkaline sucrose gradients}

The lysates from the same experiment were centrifuged in alkaline sucrose gradients (Fig. 4). Some ${ }^{3}$ H.labeled material still sediments to the bottom of the tube in samples taken early in the latent period, but here this is not the only component in the gradient.

TABLE 2

Distribution in sucrose density-gradients of radioactive material incorporated during 1-min pulses of $\left[{ }^{3} \mathrm{H}\right]$ thymidine administered after infection with $c_{1}$ phage

\begin{tabular}{cccc}
\hline $\begin{array}{c}\text { Beginning of } \\
\text { pulse (min } \\
\text { after infection) }\end{array}$ & $\begin{array}{c}\text { Radioactivity } \\
\text { incorporated } \\
\text { (cts/min per } \\
0.1 \text { ml.) }\end{array}$ & $\begin{array}{c}\text { Total radio- } \\
\text { activity } \\
\text { recovered } \\
(\%)\end{array}$ & $\begin{array}{c}\text { Proportion } \\
\text { recovered at } \\
\text { the bottom } \\
(\%) \dagger\end{array}$ \\
\hline 5 & 727 & 82 & 56 \\
10 & 564 & 78 & 59 \\
15 & 2115 & 84 & 63 \\
20 & 4422 & 88 & 59 \\
25 & 6656 & 78 & 62 \\
30 & 7612 & 79 & 58 \\
35 & 8130 & 81 & 56 \\
40 & 1624 & 92 & 45 \\
\hline Uninfected control & 1731 & 90 & 18 \\
\hline
\end{tabular}

Strain 18 cells growing exponentially at $37^{\circ} \mathrm{C}$ were infected with $20 c_{1}$ phage per cell. Pulses were begun by adding $1 \mathrm{ml}$. of culture to $20 \mu \mathrm{c}(17 \mathrm{c} / \mathrm{m} \cdot \mathrm{mole})$ of $\left[{ }^{3} \mathrm{H}\right]$ thymidine and terminated 1 min later by adding an equal volume of the lysis mixture. The conditions of lysis and sucrose gradient analysis were the same as those described in the legend to Table 1 . The number of fractions per gradient varied from 28 to 33 .

$\dagger$ Calculated as described in the legend to Table 1. 
Comparison of frame 1 of Figure 4 with the same frame of Figure 3 shows that much of the material at the bottom in neutral gradients sediments in a broad band near the top of the alkaline ones; this band has components sedimenting both more slowly and more rapidly than the phage DNA marker. However, during the chase (frames 2 through 5), there is pulse-labeled material which sediments in alkali at a rate of 1.2 to 1.5 times the rate of mature DNA. In alkaline as well as in neutral gradients, virtually all the labeled DNA sediments at the rate characteristic of mature phage DNA by the time spontaneous lysis occurs (frames 6 and 7 ).

(d) Sedimentation behavior of DNA pulse-labeled after infection

Pulse-labeling at various times after infection with $c_{1}$ phage (Table 2) gives the same results as after induction (Table 1 ). In both cases, most of the $\left[{ }^{3} \mathrm{H}\right]$ thymidine incorporated in all pulses administered after the onset of phage DNA synthesis is found at the bottom of neutral sucrose gradients, i.e. in intermediate I.

(e) Fate of parental and pulse-labeled DNA after infection

A [ $\left.{ }^{3} \mathrm{H}\right]$ thymidine pulse and chase experiment similar to the one described above was performed, in this case with cells infected with ${ }^{32}$ P-labeled $c_{1}$ phage. Some of the

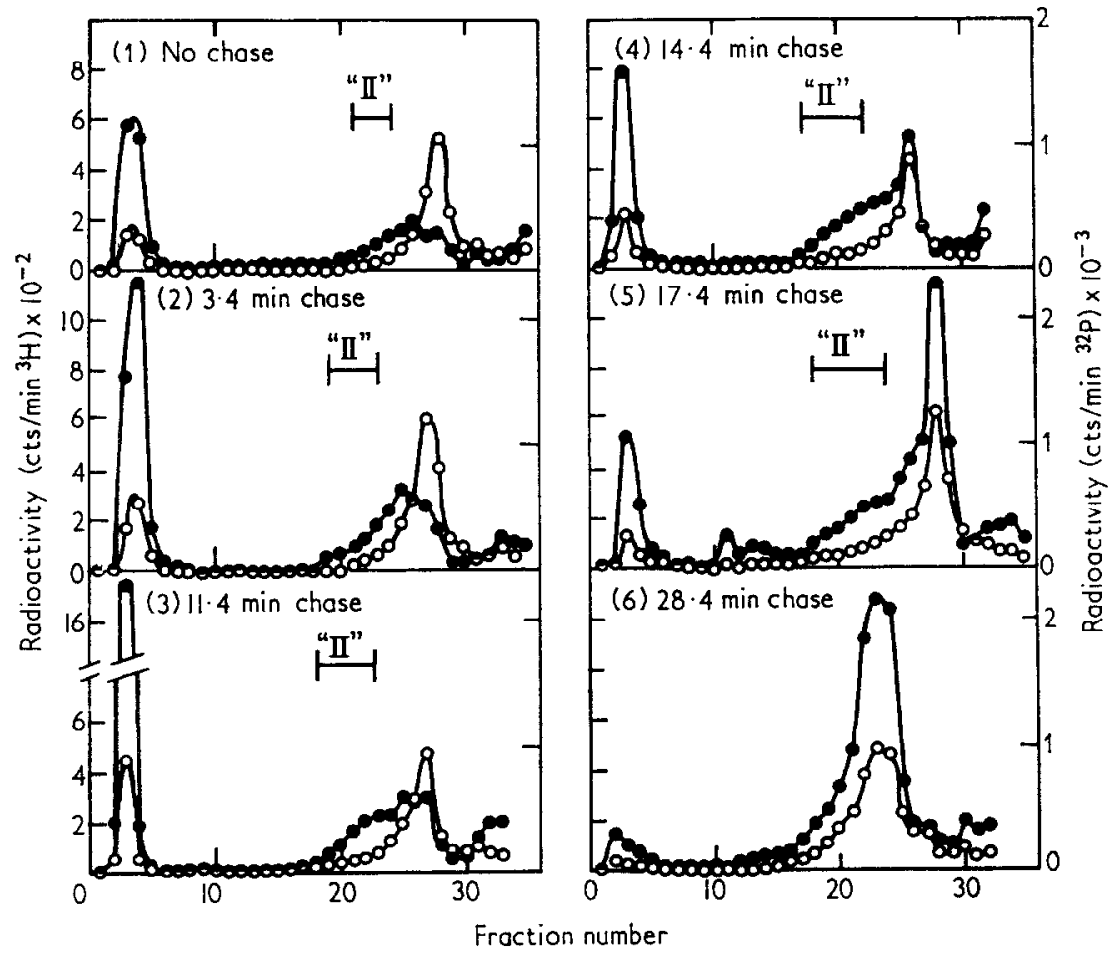

Fig. 5. The fate of parental and pulse-labeled phage DNA after infection with $c_{1}$ phage: neutral sucrose gradients.

Strain 18 cells were infected with $20^{32} \mathrm{P}$-labeled $c_{1}$ phage per cell to begin the experiment. $\left[{ }^{3} \mathrm{H}\right]$ Thymidine $(20 \mu \mathrm{c} / \mathrm{ml}$; $17 \mathrm{c} / \mathrm{m}$-mole $)$ was added 8 min after infection; $2 \mathrm{mg}$ of unlabeled thymidine/ml. was added 2 min later. Samples were lysed as described in Materials and Methods. Neutral sucrose gradients of the usual composition were centrifuged for $60 \mathrm{~min}$ at $35,000 \mathrm{rev} . / \mathrm{min}$ at $23^{\circ} \mathrm{C}$. Collection and analysis of the gradients was performed in the usual way. Recovery of ${ }^{32} \mathrm{P}$-radioactivity was always better than $90 \%$; of ${ }^{3} \mathrm{H}$ radioactivity always better than $87 \%$. $(-\mathrm{O}-\mathrm{O}-)^{32} \mathrm{P}$ radioactivity; $(-\mathbf{-}-)^{3} \mathrm{H}$ radioactivity. 
${ }^{32}$-labeled DNA initiates the infection and is followed through the subsequent pulse-chase experiment. In addition, some of the ${ }^{32} \mathrm{P}$-labeled DNA sediments near the top of the gradient (Fig. 5, frame 1). This DNA was shown to have the same sedimentation rate as purified ${ }^{3} \mathrm{H}$-labeled phage $\mathrm{DNA}$, and thus still serves as a marker for the mature phage DNA position.

\section{(i) Sedimentation through neutral sucrose gradients}

The distribution of the ${ }^{3} \mathrm{H}$ pulse-labeled DNA as the infection proceeds corresponds to the pattern found after temperature induction. At first the major component is intermediate I, at the bottom of the gradient. Later, intermediate II emerges at a position indicating a sedimentation rate 1.3 to 1.7 times the sedimentation rate of the mature phage DNA. Eventually (at the time of spontaneous lysis) most of the label accumulates in a position identical to that of mature phage DNA.

It is apparent from Figure 5 that there is parental label associated with intermediate $I$, as well as in the position of mature phage DNA. This is consistent with the notion that intermediate $I$ is the replicating form.

(ii) Sedimentation through alkaline sucrose gradients

The results of alkaline sucrose gradients (Fig. 6) are again similar to those obtained following temperature induction. Again much of the pulse-label is at first (frame 1)

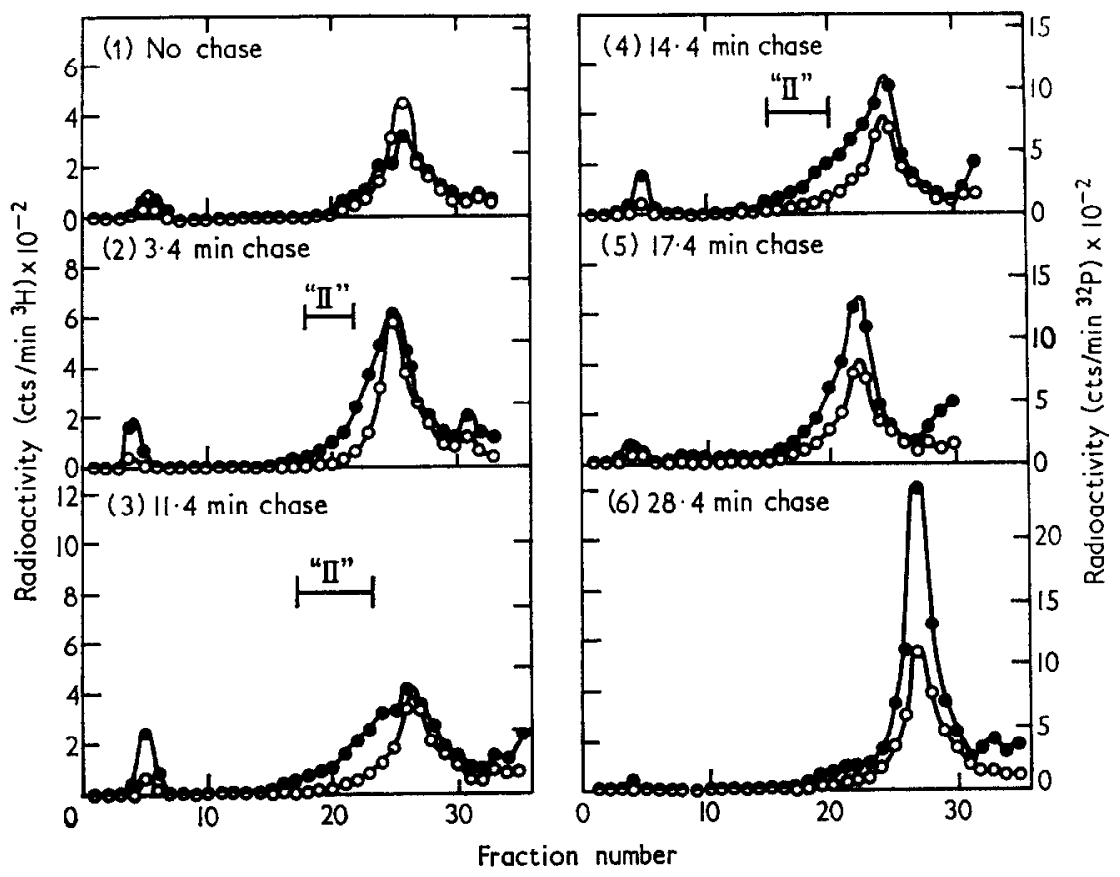

Fra. 6. The fate of parental and pulse-labeled phage DNA after infection with $c_{1}$ phage: alkeline sucrose gradients.

The origin of the lysates is described in the legend to Fig. 5. The preparation of the alkaline gradients and the adjustment of the $\mathrm{pH}$ of the lysates are described in the Materials and Methods section. Sedimentation was for $90 \mathrm{~min}$ at $35,000 \mathrm{rev} . / \mathrm{min}$ at $23^{\circ} \mathrm{C}$. The recovery of ${ }^{32} \mathrm{P}$ radioactivity was always better than $86 \%$; of ${ }^{3} \mathrm{H}$ radioactivity always better than $79 \%$. (-O-O-) ${ }^{32} \mathrm{P}$ radioactivity; (-0-0-) ${ }^{3} \mathrm{H}$ radioactivity. 
near the mature phage position, although some pulse label (and a small amount of ${ }^{32} \mathrm{P}$ ) still sediments to the bottom. Later, when intermediate II is apparent in the neutral gradients, there is in the alkaline gradients a component which sediments somewhat more rapidly than the mature phage DNA (frames 2, 3 and 4 of Fig. 6). These experiments indicate that the pattern of intermediate forms is found in both infection and induction.

\section{(iii) Comparison of the fates of parental and pulse-labeled phage DNA}

Both parental and newly synthesized phage DNA appear in intermediate I (Fig. 5). Participation of parental DNA in intermediate II as well is suggested by the data in Table 3. Intermediate I has a characteristic ratio of ${ }^{3} \mathrm{H}$ (newly synthesized DNA) to ${ }^{32} \mathrm{P}$ (parental DNA) throughout the latent period. Although the proximity of the

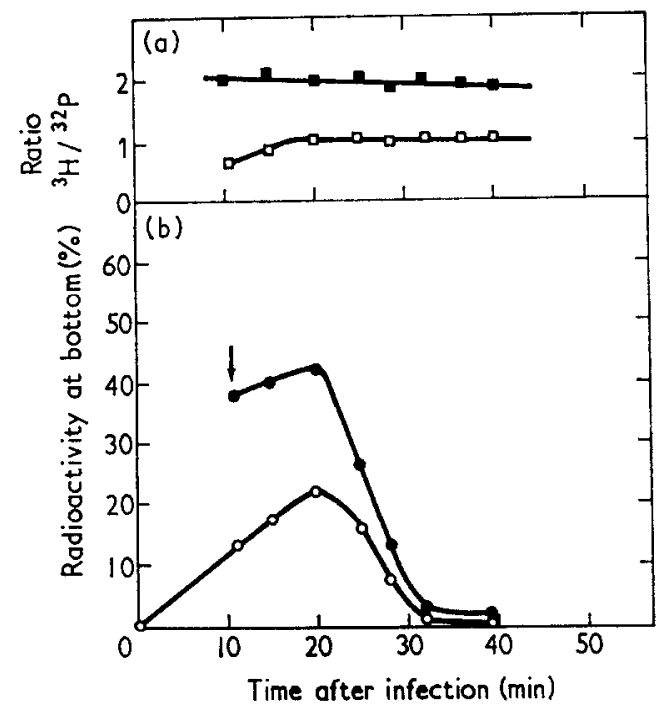

Fia. 7. The proportions of parentel and pulse-labeled phage DNA in intermediate I at various times after infection with $c_{1}$ phage.

The date are derived from the gradients of Fig. 5 .

(a) The ratio of ${ }^{3} \mathrm{H}$ radioactivity (pulse-labeled DNA) to ${ }^{32} \mathrm{P}$ radioactivity (parental DNA) in the unfractionated lysate (- $\square-\square-$ ) and in the first 6 fractions of each gradient (bottom fraction; - - - - .

(b) The proportion of ${ }^{3} \mathrm{H}$ radioactivity (pulse-labeled DNA; - - - - -) and ${ }^{32} \mathrm{P}$ radioaotivity (parental DNA; - $\mathrm{O}-\mathrm{O}-$ ) recovered in the first 6 fractions of oxch of the gradients in Fig. 5 (bottom fraction).

mature phage DNA peak to the intermediate II region in the gradients (Fig. 5) makes calculation of the ratio throughout the intermediate II peak impossible, the ratio in the leading edges of the intermediate II peaks is the same as the ratio in intermediate I, and different from the ratio in the unfractionated lysate.

The constancy of the ${ }^{3} \mathrm{H} /{ }^{32} \mathrm{P}$ ratio in intermediate $\mathrm{I}$ during the early part of the latent period is difficult to interpret†. However, the fact that the ratio is constant

$\dagger$ Detailed kinetic analysis is not justified during the first $10 \mathrm{~min}$ after the addition of unlabeled thymidine because [ ${ }^{3} \mathrm{H}$ ] thymidine continues to be incorporated, at a decreasing rate, for about 5 min. The extra incorporation adds about $30 \%$ to the total radioactivity taken up. This problem should not affect the interpretation of the ${ }^{3} \mathbf{H} /{ }^{32} \mathbf{P}$ ratios during the latter half of the latent period, during which the total ${ }^{3} \mathrm{H}$ as well as the ${ }^{32} \mathbf{P}$ remain constant (Table 3, Fig. 7). 
TABLE 3

Ratio of pulse-labeled and parental DNA in intermediates after infection

\begin{tabular}{|c|c|c|c|c|c|}
\hline \multirow{2}{*}{$\begin{array}{c}\text { Time of } \\
\text { chase }\end{array}$} & \multicolumn{2}{|c|}{ Neutral gradients } & \multicolumn{2}{|c|}{ Ratio ${ }^{3} H /{ }^{32} P$} & \multirow{2}{*}{$\begin{array}{l}\text { Unfractionated } \\
\text { lysate }\end{array}$} \\
\hline & "Iet" & $\begin{array}{l}\text { ents } \\
\text { "II ", }\end{array}$ & $\begin{array}{l}\text { Alk } \\
\text { "II" }\end{array}$ & $\begin{array}{l}\text { lents } \\
\text { "II" }\end{array}$ & \\
\hline 0 & $\mathbf{2 \cdot 0}$ & $1 \cdot 8$ & 1.7 & - & 0.7 \\
\hline $3 \cdot 4$ & $2 \cdot 1$ & 1.9 & $2 \cdot 1$ & $2 \cdot 0$ & 0.9 \\
\hline $11 \cdot 4$ & $2 \cdot 0$ & 1.8 & 1.9 & 1.8 & $1 \cdot 1$ \\
\hline $14 \cdot 4$ & $1 \cdot 8$ & 1.9 & 1.8 & 1.8 & $1 \cdot 0$ \\
\hline $17 \cdot 4$ & 1.8 & $1 \cdot 7$ & $1 \cdot 8$ & 1.8 & $1 \cdot 1$ \\
\hline $28 \cdot 4$ & 1.7 & - & - & - & 1.0 \\
\hline Average & 1.9 & 1.8 & 1.9 & $1 \cdot 8$ & $1 \cdot 0$ \\
\hline
\end{tabular}

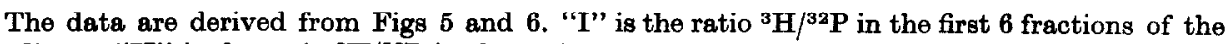
gradients. "II" is the ratio ${ }^{3} \mathrm{H} /{ }^{32} \mathrm{P}$ in the regions marked in the relevant frames of Figs 5 and 6. There are no systematic variations in ratio across these regions. Values are omitted only where the total ${ }^{32} \mathrm{P}$ radioactivity is too small to give a significant ratio.

during the latter half of the latent period, during which there is a $\mathbf{4 0}$-fold decrease in parental and newly synthesized phage DNA in intermediate I (Fig. 7) means that both kinds of DNA move out of intermediate I (and into intermediate II) together.

Table 3 also shows that the materials analogous to intermediates $I$ and $I I$ in the alkaline sucrose gradients (Fig. 6) have a ratio of ${ }^{3} \mathrm{H} /{ }^{32} \mathrm{P}$ characteristic of the intermediates.

In a $\mathrm{CsCl}$ equilibrium density-gradient (Weigle, Meselson \& Paigen, 1959), progeny phage from this experiment formed a single symmetrical band, in which the ${ }^{3} \mathbf{H},{ }^{32} \mathbf{P}$, and plaque-forming units are superimposed. About 70\% of the ${ }^{3} \mathrm{H}$-labeled DNA, and $30 \%$ of the ${ }^{32} \mathrm{P}$-labeled (parental) DNA were recovered in the progeny. The ratio of ${ }^{3} \mathrm{H} /{ }^{32} \mathrm{P}$ in the progeny (1.9) corresponds to the ratio found in the intermediates, and not to the ratio in the unfractionated lysates.

The decrease in the proportion of pulse-labeled DNA and parental DNA found in intermediate I begins abruptly at about 20 minutes after infection (Fig. 7(b)), corresponding to the onset of late phage functions (Levine, unpublished results). This suggests that the transfer of labeled DNA from the form extracted as intermediate I into the form extracted as intermediate II is itself a late phage function.

\section{(f) Identification of pulse-labeled DNA by DNA-DNA hybridization}

Selected lysates from the pulse-chase experiments after induction and after infection were examined by DNA-DNA hybridization on nitrocellulose filters (Denhardt, 1966) (Table 4). The substantial variations in the recovery on filters (see Materials and Methods) make detailed quantitative evaluation of the data difficult. However, since the ratio of phage-binding and bacterial-binding activity did not vary greatly, the qualitative result is clear. Pulse-label is incorporated mainly into polynucleotide chains homologous to those of phage DNA. Furthermore, the ratio of phage-binding to bacterial-binding activity is the same immediately after pulse-labeling as it is near the end of the latent period. These results verify that the DNA analyzed here is primarily phage DNA. 


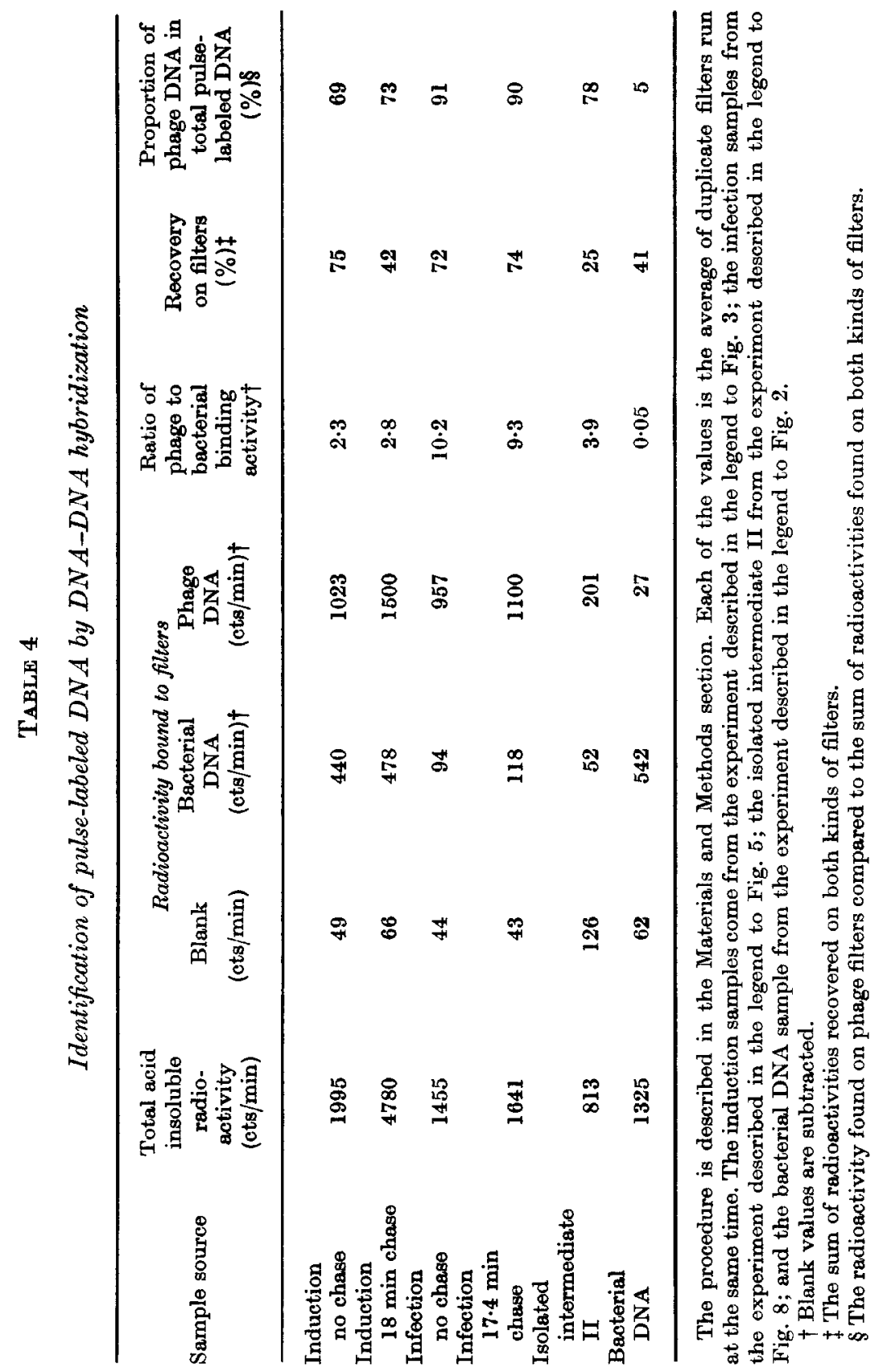




\section{(g) Sedimentation behavior of isolated intermediate II}

Intermediate II sediments somewhat more rapidly than mature phage DNA in neutral sucrose gradients. A similar species was found, at the same times during the latent period, in alkaline sucrose gradients. In order to clarify the nature of this unusual form of DNA, intermediate II was isolated from a neutral sucrose gradient run without detergent, dialyzed, and treated extensively with pronase (see legend to Fig. 8). This material hybridizes primarily with phage DNA (Table 4).

The isolated material was centrifuged through a neutral and an alkaline sucrose gradient together with purified ${ }^{32} \mathrm{P}$-labeled phage DNA marker. The conditions were arranged so as to approximate as closely as possible to the conditions used by Studier (1965). These manipulations have not abolished the increased sedimentation rate of intermediate II in neutral gradients (Fig. 8(a)). In alkali (Fig. 8(b)), the average sedimentation rate of isolated intermediate II is $\mathbf{1 . 2}$ times the sedimentation rate of the mature phage DNA marker. The fact that the intermediate II DNA bands in

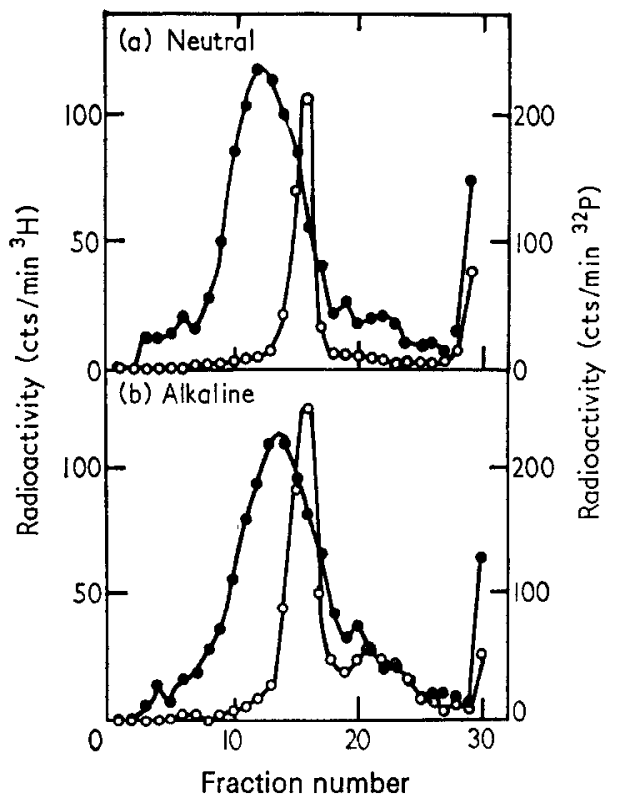

FIG. 8. Sedimentation rate of isolated intermediale II.

Strain 18 cells infected with $20 c_{1}$ phage/cell were labeled with [ $\left.{ }^{3} \mathrm{H}\right]$ thymidine $(5 \mu \mathrm{c} / \mathrm{ml} ., 17 \mathrm{c} / \mathrm{m}$ mole) in the presence of $250 \mu \mathrm{g}$ deoxyadenosine $/ \mathrm{ml}$. beginning at $10 \mathrm{~min}$ after infection. At $28 \mathrm{~min}$ after infection the cells were lysed (see Materials and Methods) and the lysate centrifuged through a 30-ml. neutral sucrose gradient together with ${ }^{32} \mathrm{P}$-labeled marker phage DNA. The gradient conteined no detergent. The fractions in the intermediate II region were pooled, treated overnight with $1 \mathrm{mg}$ pronase/ml., and dialyzed for 2 days (with more pronase) against $0.01 \mathrm{M}-$ Tris (pH 7.5).

The isolated material was mixed with purified 32 P-labeled phage DNA and appliod to tho following $5 \mathrm{ml}$. gradients: (a) 5 to $20 \%$ sucrose gradient containing $1.0 \mathrm{M}-\mathrm{NaCl}, 0.02 \mathrm{M}-$ Tris and 0.01 M-EDTA (pH 8). $0.1 \mathrm{ml}$. of the mixture was applied. (b) 5 to $20 \%$ sucrose gradient containing $0.9 \mathrm{M}-\mathrm{NaCl}, 0.1 \mathrm{M}-\mathrm{NaOH}$ (the solution was titrated to $\mathrm{pH} 12 \cdot 1$; actually, the concentration of $\mathrm{NaOH}$ is somewhat greater than $0.1 \mathrm{~m}$ ), and $0.005 \mathrm{M}-\mathrm{E} \cdot \mathrm{D}$ A. $0.1 \mathrm{ml}$. of $0.25 \mathrm{M}-\mathrm{NaOH}$ was layered on the gradient before the application of the sample $(0.1 \mathrm{ml}$. also). The completely layered gradient was allowed to stand for $30 \mathrm{~min}$ before centrifugation.

Centrifugation in both (a) and (b) was for $135 \mathrm{~min}$ at $35,000 \mathrm{rev} . / \mathrm{min}$ at $23^{\circ} \mathrm{C}$. In both (a) and (b) there was better than $85 \%$ recovery of all radioactivities. ( $-\mathrm{O}-\mathrm{O}-$ ) ${ }^{32}$ P radioactivity (purified phage DNA marker); (- - - ${ }_{-}^{3} \mathrm{H}$ radioactivity (isolated intermediate II). 
Figure 8 are much broader than the marker DNA bands indicates that intermediate II is heterogeneous with respect to sedimentation rate in both neutral and alkaline gradients.

The alkaline sedimentation behavior of isolated intermediate II suggests that much of the material in the pulse-chase experiments sedimenting 1.2 to 1.5 times more rapidly than mature phage DNA in alkali, derives from intermediate II DNA.

\section{Discussion}

The experimental results may be summarized as follows:

(1) Most of the $\left[{ }^{3} \mathrm{H}\right]$ thymidine incorporated in a one-minute pulse administered at any time after the onset of phage DNA synthesis, be it after induction of a temperatureinducible lysogen or after infection with $c_{1}$ phage, is extracted in a form (intermediate I) which sediments in neutral sucrose density-gradients at a rate exceeding $1000 \mathrm{~s}$. This material hybridizes primarily with phage DNA and is distinguishable in sedimentation coefficient from the bacterial DNA of uninfected cells (about $250 \mathrm{~s}$ ) and mature phago DNA (33 s; Studier, personal communication).

(2) If a short pulse is followed by a chase with unlabeled thymidine, material disappears from intermediate I and appears in another form (intermediate II) which has a sedimentation coefficient 1.3 to 1.7 times the sedimentation coefficient of the mature phage DNA, i.e. 43 to $56 \mathrm{~s}$.

(3) Eventually most of the pulse-label is chased into a form indistinguishable in sedimentation coefficient from the mature phage DNA. About two-thirds of the pulselabel is recoverable in the progeny phage particles. Most of the DNA labeled in the pulse can be identified as being homologous to mature phage DNA by DNA-DNA hybridization.

(4) If infection is carried out with $20{ }^{32} \mathrm{P}$-labeled $c_{1}$ phage per bacterium, parental phage DNA appears in intermediate I early in the latent period and can be detected in a position corresponding to intermediate II at later times.

(5) When intermediate II is found in neutral gradients, a corresponding material sedimenting 1.3 to 1.5 times as rapidly as mature phage DNA is found in the alkaline gradients as well. Isolated intermediate II retains its high sedimentation coefficient after treatment with pronase and extensive dialysis; material sedimenting 1.3 times as rapidly as mature phage DNA in neutral sucrose gradients sediments at 1.2 times the mature phage rate in alkaline sucrose gradients.

(6) Much of the material in intermediate I has a sedimentation rate near the rate of mature phage DNA in alkali.

(7) The disappearance of intermediate I after pulse and chase coincides with the onset of late phage functions.

(8) The ratio of pulse-labeled DNA to parental DNA after infection with ${ }^{32}$ P-labeled phage suggests that both kinds of DNA move through the sequence of intermediates together.

(9) Infection with ${ }^{32} \mathrm{P}$-labeled phage followed by pulse and chase with $\left[{ }^{3} \mathrm{H}\right]$ thymidine yields progeny phage particles having a ratio of the two radioactivities identical with that found in the intermediates.

No attempt has been made in most of the experiments to purify labeled DNA before analysis in sucrose density-gradients. On the contrary, every effort has been made to 
preserve the integrity of the labeled DNA by minimizing mixing and handling of the lysates. Large concentrations of detergent and chelating agents have been employed to minimize enzymic degradation of the labeled DNA. The high sedimentation coefficient of labeled bacterial DNA obtained with these methods may be an indication of the success of this approach; the approximate sedimentation coefficient of $250 \mathrm{~s}$ obtained for bacterial DNA somewhat exceeds the theoretical value calculated for intact chromosomes from the equations of Studier (1965).

\section{(a) Physiological role of intermediate $I$}

Others have reported experiments (Kozinski \& Lin, 1965; Smith \& Burton, 1966; Frankel, 1966a; Smith \& Skalka, 1966; Saltzman \& Weissbach, 1967; Young \& Sinsheimer, 1967) in which intracellular phage DNA has been examined. In several cases, materials resembling intermediate I have been detected. In particular, Smith \& Burton (1966) found that almost all of the pulse-labeled and half of the total intracellular DNA in T5-infected Escherichia coli lysed with detergent, remain at the interface between the aqueous and phenol phases after gentle extraction with phenol. The amount of phage DNA in this form, as a function of time after infection, indicates that the DNA recovered at the phenol-water interface may have a physiological role in T5 infection similar to the one apparently taken by intermediate I in P22 infection. A similar situation was observed after T4 infection by Frankel (1966a) and by Kozinski \& Lin (1965), who also found ${ }^{32}$ P-labeled parental phage DNA at the phenol-water interface.

Frankel (1966a) and Smith \& Burton (1966) attribute the extraordinary properties of "interface DNA" and similar species to trapping of replicating DNA by the rigidwall structures of the disrupted bacteria. Smith \& Skalka (1966) have found such structures upon examining the phenol-water interface in the electron microscope. All these authors report that DNA found in the phenol-water interface may be removed from this fraction by the action of lysozyme. They also find that pulse. labeled DNA does not appear at the phenol-water interface if lysozyme treatment precedes lysis with detergent. Frankel (1966a) reports that conditions which cause trapping of newly synthesized phage DNA, also cause trapping of the bacterial DNA, although all authors agree that mature phage DNA is not trapped.

It is unlikely that trapping of newly synthesized phage DNA by the rigid-wall structures of bacteria can account for the properties of intermediate $I$ for the following reasons.

(1) Most of the pulse-labeled or uniformly labeled bacterial DNA of uninfected bacteria lysed as described in Materials and Methods sediments much more slowly than intermediate $I$, but at a rate consistent with little or no degradation.

(2) Intermediate I is formed when phage DNA synthesis has just begun. A temperature-sensitive phage mutant unable to synthesize DNA in measurable quantities nevertheless contributes parental phage DNA to intermediate I (Botstein \& Levine, 1968).

Artifacts due to the random aggregation of DNA are also unlikely. In addition to the above reasons, labeled DNA from phage added to the lysis mixture and lysed together with infected or induced cells does not appear in intermediate $I$, even though parental phage DNA does appear in intermediate I after infection with ${ }^{32}$ P-labeled phage. 


\section{(b) Nature of intermediate $I$}

The composition of intermediate $I$ is not known. The extremely high sedimentation coefficient of intermediate I suggests, however, that it is not composed entirely of DNA, since such a molecule of DNA would have to be hundreds of phage-length pieces long. It is much more likely that intermediate $I$ is the result of a specific physical or chemical association between phage DNA and some other constituent in the cell, possibly the cell membrane (Jacob, Brenner \& Cuzin, 1963; Cuzin \& Jacob, 1967; Ganesan \& Lederberg, 1965). This association appears to be a normal (very possibly essential) step in the phage DNA replication process. This conclusion is supported by the observation that the release of newly synthesized phage DNA from the complex in the cell (which upon extraction is intermediate I) begins simultaneously with the onset of late phage functions. Kozinski \& Lin (1965) came to a similar conclusion regarding the physiological role of DNA recovered at the phenol-water interface after infection of $E$. coli with T4 phage.

About two-thirds of the pulse-labeled DNA in intermediate I, when examined in alkaline sucrose gradients immediately after pulse-labeling, sediments as a broad band completely overlapping the reference DNA band. Since the material sedimenting more slowly than mature phage DNA disappears during the chase, it may represent incomplete new DNA strands. The existence of the more rapidly sedimenting component may indicate that the production of DNA with the alkaline sedimentation rate characteristic of intermediate II may occur while this DNA is still in the synthesis complex. Studies with a phage mutant which apparently accumulates DNA in intermediate I (described in the following paper (Botstein \& Levine, 1968)) support this view. In any event, it appears that much of the DNA in intermediate I, despite the huge sedimentation coefficient, consists of polynucleotide strands of approximately the same length as those of mature phage DNA.

Although intermediate I appears to be the first intermediate in phage DNA synthesis, these experiments would not have detected possible precursors with short life-times. Extensive DNA synthesis cannot be required for the appearance of parental phage DNA in intermediate $I$, since normal amounts of parental phage DNA appear in intermediate $I$ after infection with a temperature-sensitive phage mutant unable to synthesize measurable amounts of DNA (Botstein \& Levine, 1968).

\section{(c) Nature of intermediate $I I$}

More is known about the nature of intermediate II. It is likely that DNA in this form does not replicate as such. This conclusion is based on the observation that little, if any, pulse-label is incorporated directly into this form, even if the pulse is administered late in the latent period. The same argument applies to the possibility that mature phage DNA replicates as such. Intermediate II appears to be a derivative of intermediate $I$, since the ratio of pulse-labeled to parental phage DNA in intermediate II is the same as that found in intermediate $I$.

Analysis of isolated intermediate II shows that it could be the source of much of the DNA which was found to sediment somewhat more rapidly than mature phage DNA in alkaline sucrose gradients. This increased sedimentation rate appears to be unaffected by prolonged incubation with pronase, making it unlikely that the increased sedimentation rate is due to attachment of DNA to protein. Intermediate II probably does not represent a closed circular duplex form of DNA resembling the polyoma or lambda circular forms (Vinograd \& Lebowitz, 1966; Young \& Sinsheimer, 
1964; Bode \& Kaiser, 1965), since the alkaline sedimentation rate of such material should be much greater than that observed for intermediate II. Furthermore, although the buoyant density of intermediate II DNA in alkaline $\mathrm{CsCl}$ equilibrium densitygradients is unusual (Botstein, unpublished results) it does not have the greatly increased density expected of closed circular DNA (Vinograd \& Lebowitz, 1966).

The most likely explanation for the unusual behavior of intermediate II DNA is that its polynucleotide strands are longer than those of the mature phage DNA. The strongest argument for this interpretation is that the difference in sedimentation rate between intermediate II DNA and mature phage DNA is about the same in neutral and alkaline sucrose gradients (Studier, 1965). If the relative sedimentation coefficients are accurate, the polynucleotide strands of intermediate II DNA would be from two to five times as long as those of the mature DNA.

The ratio of ${ }^{3} \mathrm{H}$-radioactivity (pulse-labeled phage DNA) to ${ }^{32} \mathrm{P}$ radioactivity (parental phage DNA) after infection with ${ }^{32} \mathrm{P}$-labeled phage followed by pulse and chase of $\left[{ }^{3} \mathrm{H}\right]$ thymidine is the same in the intermediates and the progeny phage particles, but different from the ratio in the unfractionated lysate. This implies that the replicated DNA in the intermediates is the preferred source of DNA for encapsulation into phage heads. This, in turn, means that the mature phage DNA which arises from the conversion of intermediate DNA must be distinguished in some way from unreplicated parental phage DNA which is not encapsulated. The need to invoke such a distinction disappears if the substrate for encapsulation is not mature phage DNA but intermediate II.

\section{(d) $A$ model for the replication of P22 DNA}

A simple scheme can be constructed to describe the synthesis and maturation of phage P22 DNA. Upon infection, parental phage DNA molecules are injected into the host cell. Some of these molecules are then attached to a synthesis complex (which upon extraction becomes intermediate I) where replication takes place. The replicated phage DNA is removed from the synthesis complex as the consequence of a late phage function and becomes, upon extraction, intermediate II. The structure of intermediate II DNA is altered again to produce mature phage DNA, possibly as a consequence of encapsulation of the DNA into phage heads.

If intermediate II DNA consists of polynucleotide strands longer than those of the mature phage DNA, and the genome is repeated over and over in this molecule, then the scheme as outlined will perpetuate the circular permutation and terminal repetition of the information encoded in phage P22 DNA (Rhoades et al., manuscript in preparation) in the manner proposed by Streisinger and his collaborators (Streisinger et al., 1964; Sèchaud et al., 1965; Streisinger et al., 1967).

Many of these assumptions can be tested by the use of conditional lethal mutants having deficiencies in the synthesis and maturation of phage DNA. Such mutants are the subject of the following communication (Botstein \& Levine, 1968).

I wish to acknowledge the help and advice of Dr Myron Levine and Dr H. O. Smith during the course of this work. I am also indobtod to Dr E. R. Signor and to Dr M. S. Fox for criticism of the manuscript. I wish also to thank Mrs L. Gough for help with the hybridization experiments.

This work was supported hy grant GM-09252-05 from the National Tnstitutes of Health to the Department of Human Genetics. I was supported by National Institutes of Health training grant no. 5-T01-GM-00071-9 to the University of Michigan. 


\section{REFERENCES}

Bode, V. C. \& Kaiser, A. D. (1965). J. Mol. Biol. 14, 399.

Botstein, D. (1967). Bact. Proc.. p. 161.

Botstein, D. \& Levine, M. (1968). J. Mol. Biol. 34, 643.

Britten, R. J. \& Roberts, R. B. (1960). Science, 131, 32.

Cuzin, F. \& Jacob, F. (1967). In Regulation of Nucleic Acid and Protein Biosynthesis, ed. by V. V. Konigsberger \& L. Bosch. Amsterdam: Elsevier.

Denhardt, D. T. (1966). Biochem. Biophys. Res. Comm. 23, 641.

Frankel, F. R. (1966a). J. Mol. Biol. 18, 109.

Frankel, F. R. (1966b). J. Mol. Biol. 18, 127.

Frankel, F. R. (1966c). J. Mol. Biol. 18, 144.

Ganesan, A. T. \& Lederberg, J. (1965). Biochem. Biophys. Res. Comm. 18, 824.

Gough, M. \& Levine, M. (1968). Genetics, 58, 161.

Jacob, F., Brenner, S. \& Cuzin, F. (1963). Cold Spr. Harb. Symp. Quant. Biol. $28,329$.

Kozinski, A. W. \& Lin, T. H. (1965). Proc. Nat. Acad. Sci., Wash. 54, 273.

Levine, M. (1957). Virology, 3, 22.

Levine, M. \& Curtiss, R. (1961). Genetics, 46, 1573.

Levine, M. \& Smith, H. O. (1964). Science, 146, 1581.

Rubenstein, I., Thomas, C. A. Jr. \& Hershey, A. D. (1961). Proc. Nat. Acad. Sci., Wash. 47, 1113.

Saltzman, L. A. \& Weissbach, A. (1967). J. Mol. Biol. 28, 53.

Sèchaud, J., Streisinger, G., Emrich, J., Newton, J., Lanford, H., Reinhold, H. \& Stahl, M. M. (1965). Proc. Nat. Acad. Sci., Wash. 54, 1333.

Smith, H. O. \& Levine, M. (1964). Proc. Nat. Acad. Sci., Wash. 52, 356.

Smith, H. O. \& Levine, M. (1965). Virology, 25, 585.

Smith, M. G. \& Burton, K. (1966). Biochem. J. 98, 229.

Smith, M. G. \& Skalka, A. (1966). J. Gen. Physiol. 49, (supplement), 127.

Streisinger, G., Edgar, R. S. \& Denhardt, G. H. (1964). Proc. Nat. Acad. Sci., Wash. 51, 775.

Streisinger, G., Emrich, J. \& Stahl, M. M. (1967). Proc. Nat. Acad. Sci., Wash. 57, 292.

Studier, F. W. (1965). J. Mol. Biol. 11, 373.

Thomas, C. A., Jr. (1966). J. Gen. Physiol. 49 (supplement), 143.

Vinograd, J. \& Lebowitz, J. (1966). J. Gen. Physiol. 49 (supplement), 103.

Weigle, J., Meselson, M. \& Paigen, K. (1959). J. Mol. Biol. 1, 379.

Young, E. T. \& Sinsheimer, R. L. (1964). J. Mol. Biol. 10, 562.

Young, E. T. \& Sinsheimer, R. L. (1967). J. Mol. Biol. 30, 165.

Zinder, N. D. (1958). Virology, 5, 291. 